\title{
NEUROCORTICAL ELECTRICAL ACTIVITY TOMOGRAPHY IN CHRONIC SCHIZOPHRENICS
}

\author{
Heloisa Veiga ${ }^{1}$, Andréa Deslandes ${ }^{2}$, Mauricio Cagy ${ }^{3}$, Adriana Fiszman ${ }^{4}$, \\ Roberto Airthon M. Piedade ${ }^{5}$, Pedro Ribeiro ${ }^{6}$
}

\begin{abstract}
Functional imaging of brain electrical activity was performed in 25 chronic medicated schizophrenics and 40 controls, analyzing the classical frequency bands (delta, theta, alpha, and beta) of 19-channel EEG during resting state to identify brain regions with deviant activity of different functional significances, using LORETA (Low Resolution Tomography) and SPM99 (Statistical Parametric Mapping). Patients differed from controls due to an excess of slow activity comprising delta + theta frequency bands (inhibitory pattern) located at the right middle frontal gyrus, right inferior frontal gyrus, and right insula, as well as at the bilateral anterior cingulum with a left preponderance. The high temporal resolution of EEG enables the specification of the deviations not only as an excess or a deficit of brain electrical activity, but also as inhibitory (delta, theta), normal (alpha), and excitatory (beta) activities. These deviations point out to an impaired functional brain state consisting of inhibited frontal and prefrontal areas that may result in inadequate treatment of externally or internally generated information.
\end{abstract}

KEY WORDS: brain mapping, EEG, LORETA (low resolution electromagnetic tomography), schizophrenia.

\begin{abstract}
Atividade elétrica neurocortical em esquizofrênicos crônicos
RESUMO - Imagens funcionais da atividade elétrica cerebral de 25 esquizofrênicos crônicos medicados e de 40 controles foram obtidas através do registro (19 canais) e da análise das faixas tradicionais (delta, teta, alfa e beta) do EEG, durante o repouso vigil. $O$ objetivo foi identificar regiões do cérebro que apresentassem desvios com diferentes significados funcionais na 'Low Resolution Electromagnetic Tomography' (LORETA) e no 'Statistical Parametric Mapping' (SPM). Observou-se excesso de atividade lenta nas faixas delta + teta (padrão inibitório) nos pacientes esquizofrênicos, localizado no giro frontal médio direito, no giro frontal inferior direito e na insula direita e, também, na porção anterior do giro do cíngulo, bilateralmente, mas com predomínio à esquerda. A alta resolução temporal do EEG permite especificar os desvios em termos de excesso ou déficit de atividade elétrica cerebral, bem como de atividades com um padrão inibitório (delta, teta), normal (alfa) e excitatório (beta). Os desvios encontrados apontam para comprometimento funcional cerebral que consiste no predomínio de atividade inibitória nas áreas frontais e pré-frontais que pode causar processamento inadequado de informações, quer de origem externa quanto interna.
\end{abstract}

PALAVRAS-CHAVE: mapeamento cerebral, eletroencefalografia quantitativa (EEGq), LORETA (tomografia de baixa resolução), esquizofrenia.

Over the last few years, Quantitative Electroencefalography (qEEG) has been a valuable toll in the development of new avenues to tackle crucial issues in behavioral neuroscience. Since Ingvar et al. ${ }^{1-3}$ described hypofrontality in chronic schizophrenics by a regional cerebral blood flow method, several investigations using different methods (PET, SPECT, fMRI) have reported dysfunctions in the schizophrenic frontal, pre-frontal lobe ${ }^{4-6}$, that are associated with deficits in attention, planning, and working memory ${ }^{7}$. In line with these findings, several quantitative electroencephalographic studies have also reported hypofrontality, which can be defined as a frontally pronounced slowing of EEG activity ${ }^{8-12}$. A slowing of EEG activity correlates with reduced blood flow and glucose utilization. These results have been considered the electrophysiological equivalents of hypofrontality ${ }^{9,13}$. Indeed, long before the concept

\footnotetext{
${ }^{1}$ Mestranda em Saúde Mental, Instituto de Psiquiatria, Setor de Neuroimagem Funcional, Universidade Federal do Rio de Janeiro, RJ, Brasil (IPUB-UFRJ) e Universidade Castelo Branco (PROCIHM); ${ }^{2}$ Mestranda em Saúde Mental IPUB-UFRJ; ${ }^{3}$ Doutorando em Engenharia Biomédica, UFRJ; ${ }^{4}$ Doutoranda em Psiquiatria, IPUB-UFRJ; ${ }^{5}$ Professor Adjunto III Doutor, IPUB-UFRJ; ${ }^{6}$ Professor Adjunto II PhD, Escola de Educação Física e Desportos IPUB-UFRJ; Professor Pesquisador, PROCIHM.
}

Received 6 January 2003, received in final form 3 April 2003. Accepted 8 May 2003.

Dr. Pedro Ribeiro - Setor de Neuroimagem Funcional, Instituto de Psiquiatria, UFRJ - Avenida Venceslau Brás 71 Fundos - $22290-140$ Rio de Janeiro RJ - Brasil.E-mail: ribeirops@uol.com.br 
of hypo-frontality became popular, Lemere ${ }^{14}$ described a slowing of EEG activity in schizophrenic patients, especially those with a deteriorating course of illness. Since then, many studies have stressed the relation between a slowing of EEG activity and an unfavorable course of the illness and/or negative symptoms $s^{9,15,16 .}$

Although PET and fMRI technologies have a fine spatial resolution, they only provide an indirect measure of neuronal electrical activity. Their temporal resolution is too low to discriminate the rapidly shifting patterns characteristic of actual neurophysiological processes ${ }^{17}$. On the other hand, the quantitative electroencephalogram (qEEG) has a high temporal resolution (generally 1 to 5 milliseconds), but a spatial resolution limited to the area of the electrode sites. Therefore, the interpretation of the underlying functional neuroanatomy is possible only at the level of entire cortical lobes ${ }^{17}$. Scalp distributions of EEG power bands are not directly interpretable in terms of intracerebral generator locations. To avoid this problem, Michel et al. ${ }^{18}$ and Dierks et al. ${ }^{19}$ applied the "FFT-Dipole-Approximation" for computing brain localization of EEG-generating processes. However, FFT-Approximation is limited to a particular site and is unable to generate full threedimensional (3D) images. Restriction to a distinct location does not allow a reasonable estimate of the active processes of higher brain functions.

Recently, Pascual-Marqui et al. ${ }^{20}$ and Pascual-Marqui $^{21}$ proposed a new approach to tackle this problem using LORETA (Low Resolution Electromagnetic Tomography). This method allows a direct, true 3D tomography of brain electric activity. It requires only simple constraints and no predetermined knowledge about the number of discernable source regions. Using LORETA, the high temporal resolution of the brain electric data can be analyzed separately for the different EEG frequency bands, which have different functional interpretations. This approach allows the discrimination between distinct brain electrical patterns; such as: delta, theta, alpha and beta frequency bands ${ }^{11}$. In this context, to assess whether this new imaging tool (LORETA) can detect hypofrontality in schizophrenics, we investigated medicated chronic schizophrenic patients compared to normal control subjects.

\section{METHOD}

Subjects

Twenty five (25) chronic medicated schizophrenic outpatients from the Institute of Psychiatry (Federal University of Rio de Janeiro, Brazil) were selected for this study. All the patients presented a positive clinical history of birth difficulties, brain pathology during development, head trauma, epilepsy, developmental or neurological abnormalities, and psychoactive substance abuse. The diagnostic criteria used for schizophrenia classification was that from ICD-10 and the great majority of patients had a clinical predominance of negative symptomatology. All patients were under conventional anti-psychotic medications, but one using conventional associated with an atypical, and another only atypical neuroleptic, at the moment of the EEG assessment. There were 16 males and 9 females (mean age 29.6 years \pm 7.98 SD) with a mean evolution time of 9.64 years \pm 7.12 SD. There were 40 controls recruited among students, hospital staff, and faculty members (23 males and 17 females; mean age 30.4 years $\pm 7.99 \mathrm{SD})$. The 40 volunteers were screened for psychiatric disorders and all met the exclusion criteria mentioned above for the schizophrenics. There was no significant age difference between control and patient groups. Both groups signed a consent form and the experiment was approved by the ethics committee.

\section{Data acquisition and processing}

Patients and controls were seated in a comfortably sound and light attenuated room, while 20 minutes or more of eyes-closed alert/resting EEG data were collected from the 19 mono-polar electrodes sites. International 10/ 20 System (referred to linked earlobes) for electrode placement was used with a Braintech-3000 (EMSA-Medical Instruments, Brazil).

Eye-movement (EOG) artifact was monitored with a bipolar electrode montage using two 9-mm diameter elec-

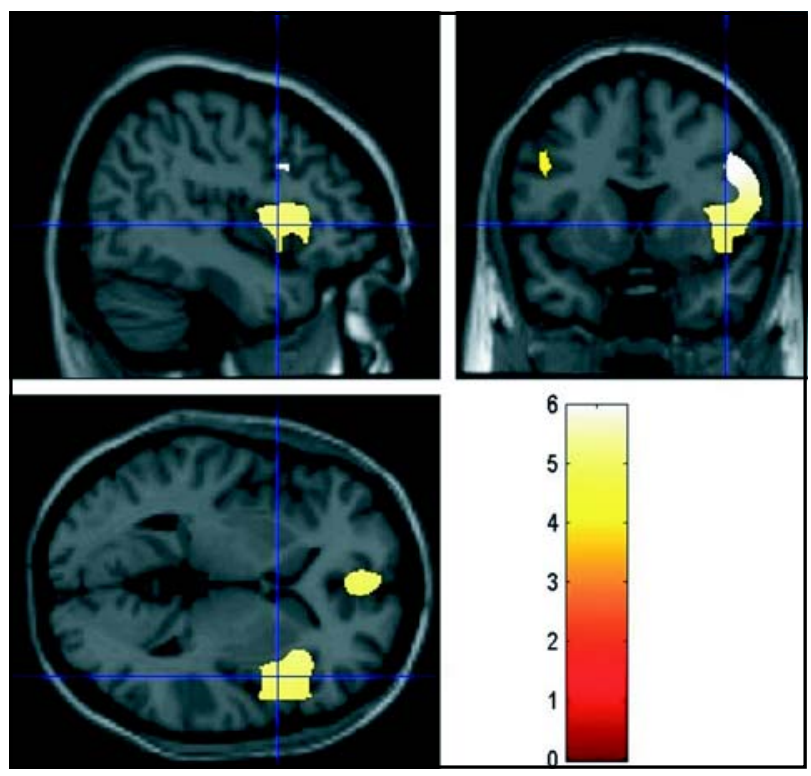

Fig 1. SPM T-statistics images (saggital, coronal and axial slices) of brain regional electric activity for slow frequency band (delta and theta), comparing 25 chronic medicated schizophrenics to 40 controls. The colored scale represents $T$ values. 
trodes attached superior to and on the external canthus of the right eye. Impendances for EEG and EOG electrodes were under $5 \mathrm{~K} \Omega$ and $20 \mathrm{~K} \Omega$, respectively. Visual inspection was employed for detection and elimination of artifacts. Moreover, Independent Component Analysis (ICA) was applied to remove possible sources of artifacts. Amplifier bandpass was $0.5-70 \mathrm{~Hz}$ ( $3 \mathrm{~dB}$ points), with a $60 \mathrm{~Hz}$ notch filter. Data were digitized at $200 \mathrm{~Hz}$ with a 12-bit resolution.

At least two minutes of artifact-free data were extracted from the EEG's total record for quantitative analysis. Power-spectral analysis was performed with Fast Fourier Transform (FFT). For each of the 19 monopolar derivations, absolute and relative (\%) power, mean frequency, interhemispheric and intra-hemispheric coherence, and symmetry were computed for the delta $(1.0-3.5 \mathrm{~Hz})$, theta $(4.0-7.5 \mathrm{~Hz})$, alpha $(8-12 \mathrm{~Hz})$, and beta $(13-25 \mathrm{~Hz})$ frequency bands. Absolute power was the only parameter used to create the functional images of neuronal electrical activity for the 4 classical bands of EEG (delta, theta, alpha, and beta) and for the 10 monopolar derivations.

\section{Functional images of neuronal electrical activity}

The 3D intracerebral distribution of neuronal electrical activity (current density) from the scalp-recorded potential distribution was assessed with Low Resolution Brain Electromagnetic Tomography (LORETA) ${ }^{20}$. LORETA computes current density at each voxel in the brain as the linear, weighted sum of the scalp electric potentials ${ }^{21}$. The 3D solution space was restricted to the cortical gray matter and hippocampus in the Talairach Atlas, as determined by the corresponding digitized Probability Atlas available from the Brain Imaging Center, Montreal Neurologic Institute ${ }^{22}$.

According to Pascual-Marqui et al. ${ }^{11}$, a voxel is labeled as gray matter if it met the following three conditions: its probability of being gray matter is higher than that of being white matter, its probability of being gray matter is higher than that of being cerebrospinal fluid, and its probability of being gray matter is higher than $33 \%$. Only those gray matter voxels that, after the Talairach Atlas, belonged to cortical and hippocampal regions were used for the analysis. A total of 2394 voxels at $7 \mathrm{~mm}$ spatial resolution were produced under these neuroanatomical constraints. LORETA represents the electrical activity at each voxel as squared magnitude (power) of the computed current density. The scalp-recorded potential distribution (power values at the 19 electrodes) for each subject and for each classical frequency bands (delta, theta, alpha and beta) in this study was transformed into LORETA functional images. In another step, each LORETA functional image was transformed to SPM99 (Statistical Parametric Mapping $)^{23}$ format, and subsequently normalized with a spatial resolution of $1 \mathrm{~mm}$ for statistical analysis. The SPM99 TTest for two independent samples was used to localize the differences of the brain electrical activity between gro-

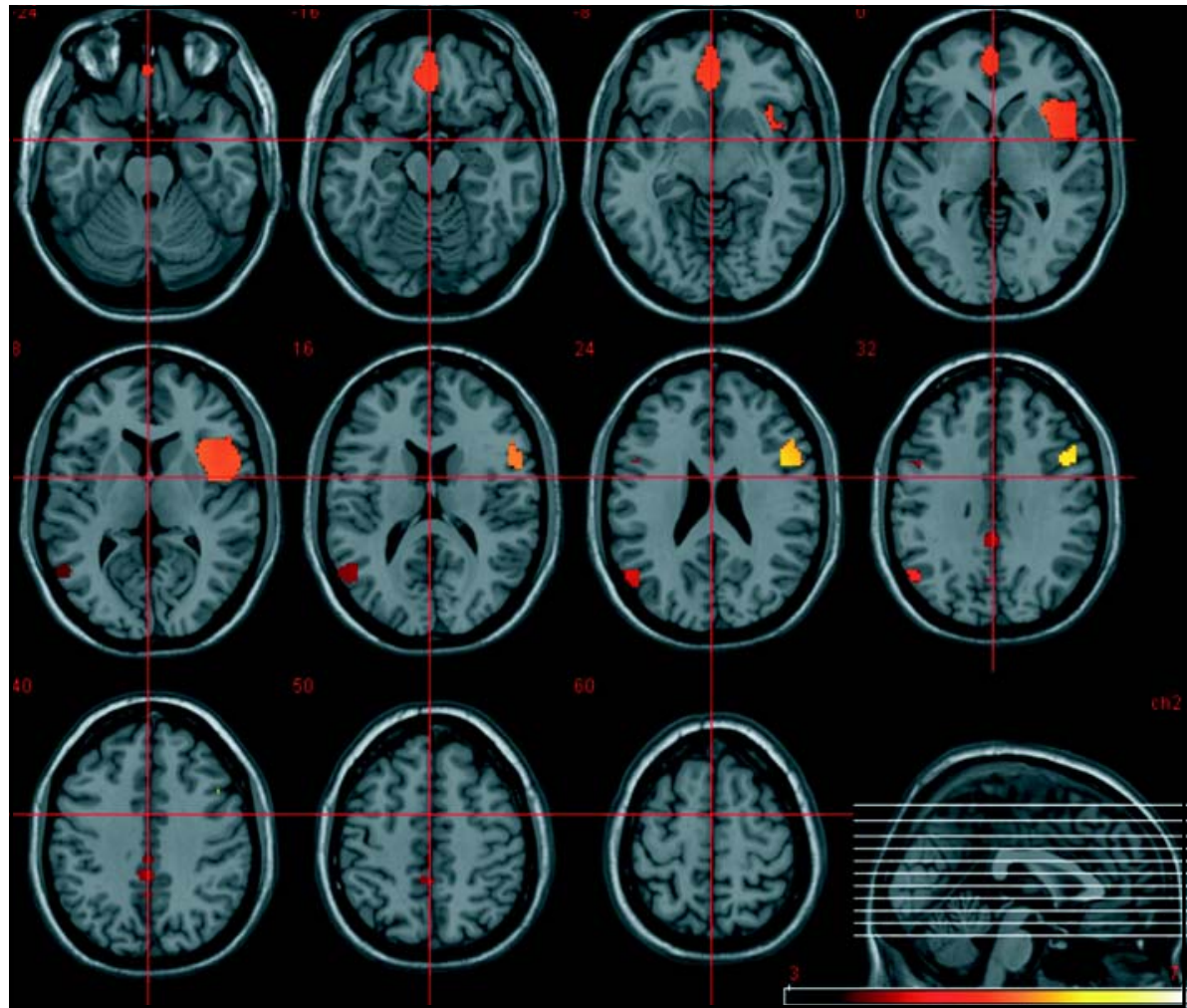

Fig 2. SPM T-statistics axial slices of brain regional electric activity for slow frequency band (delta and theta), comparing 25 chronic medicated schizophrenics to 40 controls. The colored scale represents $T$ values. 


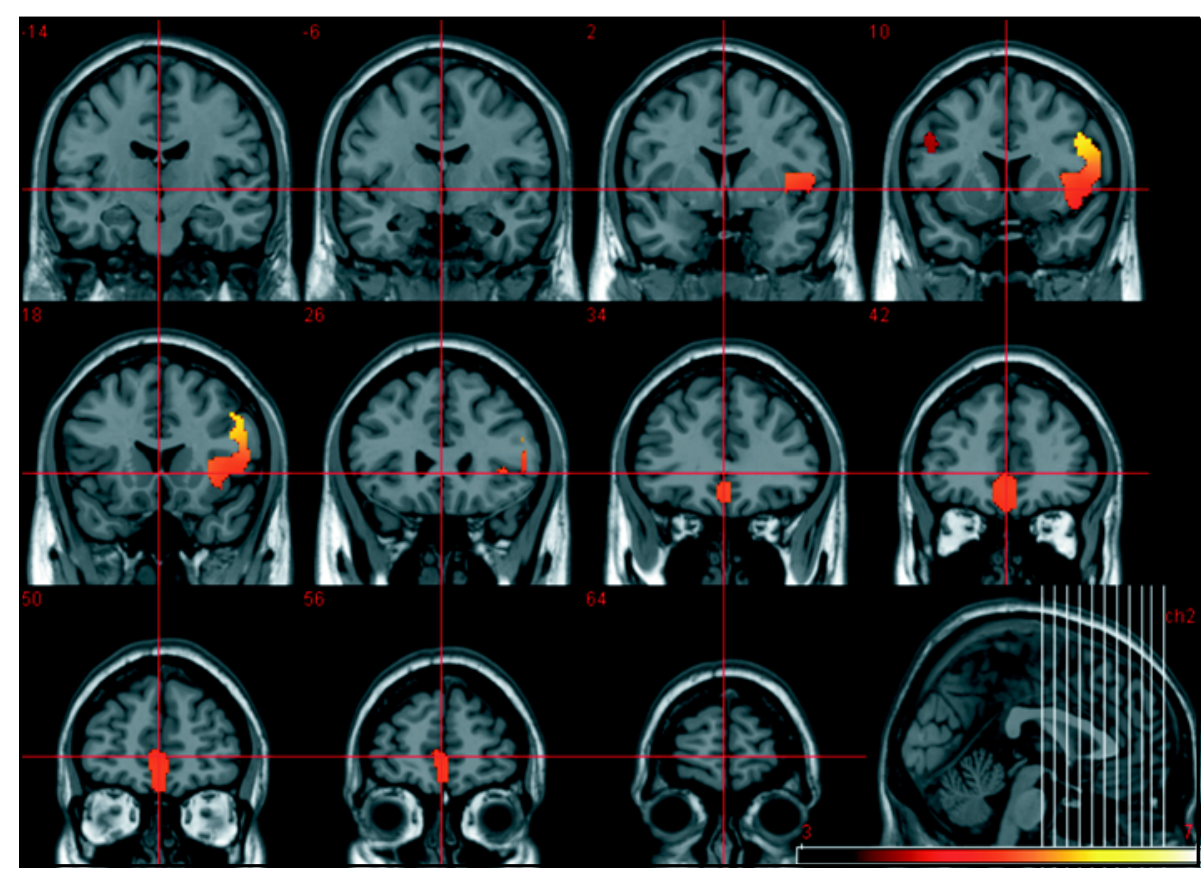

Fig 3. SPM T-statistics coronal slices of brain regional electric activity for slow frequency band (delta and theta), comparing 25 chronic medicated schizophrenics to 40 controls. The colored scale represents $T$ values.

Table 1. Brodmann areas and neuroanatomical sites.

\begin{tabular}{lccccc}
\hline Frequency band & $\begin{array}{c}\text { T-value } \\
\text { at voxel level }\end{array}$ & Corrected $\mathrm{p}$ & Side & Brodmann Area & Region \\
\hline $\begin{array}{l}\text { Delta \& theta } \\
(0.5-7.5 \mathrm{~Hz})\end{array}$ & 5.95 & 0.000 & Right & 9 and 13 & $\begin{array}{c}\text { Middle frontal gyrus } \\
\text { Inferior frontal gyrus } \\
\text { Insula }\end{array}$ \\
$\begin{array}{l}\text { Delta \& theta } \\
(0.5-7.5 \mathrm{~Hz})\end{array}$ & 5.08 & 0.000 & Bilateral & 32 & Anterior cingulum \\
\hline
\end{tabular}

Frequency bands, T-value at voxel level, corrected $\mathrm{p}$-value, side, Brodmann area and anatomical regions where the schizophrenics $(\mathrm{N}=25)$ differed with statistical significance from the controls $(\mathrm{N}=40)$.

ups (schizophrenics compared to controls), voxel-by-voxel. Each voxel is an independent variable to be compared between groups. The final result is a statistical map with the T-Test value for each voxel and its location in the brain, using the Talairach Atlas coordinates.

\section{RESULTS}

Tables 1-2 and figures 1-3 indicate the regions where the SPM99 T-Test for independent groups achieves statistical significance at $\mathrm{p} \leq 0.05$ (corrected for multiple comparisons), according to frequency bands (delta and theta). In this study, during resting condition, the schizophrenic patients differed significantly from the controls only at delta-theta frequency band in frontal areas. Hyperactivity of slow frequency (delta and theta) was observed, probably corresponding to an excess of inhibitory activity at the right frontal lobe (frontal middle gyrus, frontal inferior gyrus, and insula) and bilateral frontal areas (anterior cingulum, with a left sided preponderance).

\section{DISCUSSION}

In agreement with other reports in the literature ${ }^{8-12}$, the results of the present study point out to an increase of low band (delta + theta) power in schizophrenics when compared to normal subjects. EEG slowing was found in the frontal lobe area, specifically in the bilateral anterior cingulate cortex, right middle frontal gyrus, inferior frontal gyrus, and insula. These results are in accordance with recent anatomical and functional studies, which consistently described abnormalities of these brain areas, mainly at the anterior cingulum, in schizophrenics ${ }^{11,24-27}$. The- 
Table 2. Brain neuroelectric patterns: Delta/Theta frequency bands.

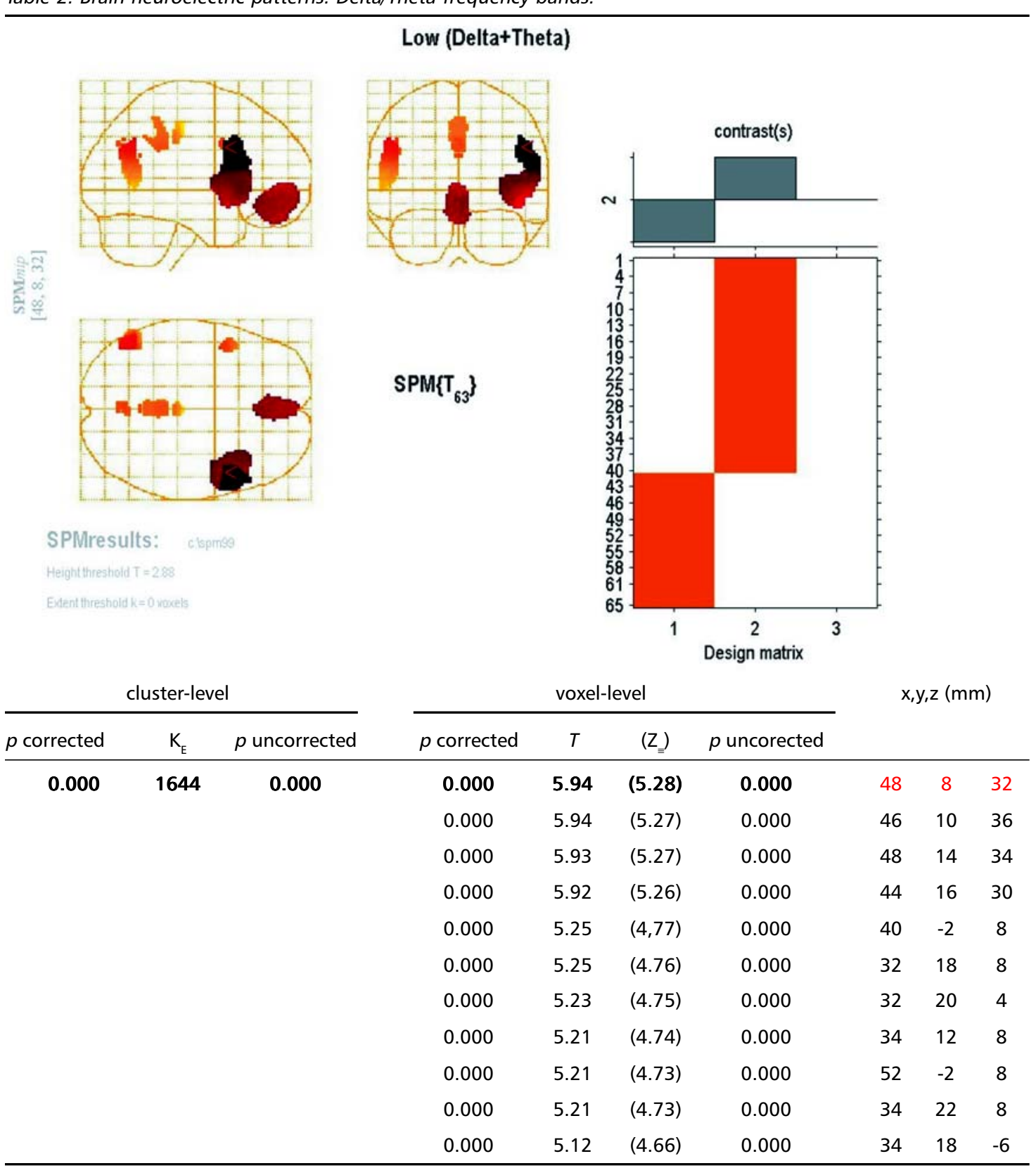

Voxel-by-voxel SPM T-statistics image of brain regional electric activity for slow frequency band (delta and theta), comparing 25 chronic medicated schizophrenics to 40 controls.

ta activity is associated with modulatory attentional demands and the individual's emotional state. Our results indicate an increment in the theta band when compared to controls, which suggests decreased metabolic activity of frontal areas. Therefore, schizophrenic patients are susceptible to express low levels of attention.

On the other hand, controversial results differ from our present investigation. A recent LORETA ana- lysis of unmedicated schizophrenic subjects that points out to a more global cortical hypofunction in schizophrenia ${ }^{28}$. An excess of activity in delta and theta bands at frontal areas, as observed in this study, is probably an indication of an active inhibitory process preponderance that is abnormal for the schizophrenics' EEGq recording condition (awake and closed eyes). Even though, Pascual-Marqui (1999) previous findings found no differences among unmedi- 
cated schizophrenic patients compared to controls. Thus, these results cannot be attributed to medication itself. Moreover, this kind of pattern is normally seen in adult sleep or in awake children. Along this vein, cortical hypofunction is related to deficits in working memory, which is described as the ability of the central nervous system to access information stored in a "buffer sector"29. In this context, our findings indicate an increase of low band frequencies at the right temporal lobe. This is not in agreement with previous studies which demonstrated that schizophrenic patients present a decreased activity in the left temporal lobe.

Taken together, the LORETA analyses in schizophrenic patients are largely consistent with findings from the literature showing electrophysiological evidence of cortical hypoactivation especially in the frontal cortex. The overall understanding is that, since all information processing is state-dependent, this disrupted brain state in schizophrenic patients provides the disposition that newly arriving (external or internal) information will be potentially treated in deviant ways. Due to their deviant state, the patients must have access to processing strategies and context material that is not available to normal individuals during adult wakefulness ${ }^{11,30}$.

\section{REFERENCES}

1. Ingvar DH, Frazen G. Distribution of cerebral activity in chronic schizophrenia. Lancet 1974;21:1484-1486.

2. Ingvar DH, Frazen G. Abnormalities of cerebral blood flow distribution in patients with chronic schizophrenia. Acta Psychiatr Scan 1974;50:425-462.

3. Ingvar DH. Evidence for frontal/prefrontal cortical dysfunction in chronic schizophrenia: the phenomenon of "hypofrontality" reconsidered. In Helmchen $\mathrm{H}$, Henn FA, (eds). Biologic perspectives of schizophrenia. Life Sciences Research Report 40. Chichester: John Wiley \& Sons, 1987:201-213.

4. Cleghorn JM, Garnett ES, Nahmias C, et al. Increased frontal and reduced parietal glucose metabolism in acute untreated schizophrenia. Psychiatry Res 1989;28:119-133.

5. Andreasen NC, Rezai K, Alliger R, et al. Hypofrontality in neurolepticnaïve patients and in patients with chronic schizophrenia. Assessment with xenon 133 single-photon emission computed tomography and the Tower of London Test. Arch Gen Psychiatry 1992;49:943-958.

6. Sabri O, Erkwoh R, Schreckenberger M, Owega A, Sass H, Buell U. Correlation of positive symptoms exclusively to hyperfusion or hypoperfusion of cerebral cortex in never-treated schizophrenics. Lancet 1997;349:1735-1739.

7. Goldberg TE, Gold JM. Neurocognitive deficits in schizophrenia. In Hirsch SR, Weinberger DR (eds). Schizophrenia, Oxford: Blackwell Science, 1995.
8. Etevenon P, Pidoux B, Rioux P, Peron-Magnan P, Verdeaux G, Deniker $P$. Intra and inter-hemispheric EEG differences quantified by spectral analysis: comparative study of two groups of schizophrenics and control group. Acta Psychiatr Scand 1979;60:57-68.

9. Guich SM, Buchsbaum MS, Burgwald L, et al. Effect of attention on frontal distribution of delta activity and cerebral metabolic rate in schizophrenia. Schizophrenia Res 1989;2:439-448.

10. John ER, Prichep LS, Alper KR, et al. Quantitative electrophysiological characteristics and subtyping of schizophrenia. Biol Psychiatry 1994;36:801-826.

11. Pascual-Marqui RD, Lehmann D, Koenig T, et al. Low Resolution Brain Electromagnetic Tomography (LORETA): functional imaging in acute, neuroleptic-naïve, first-episode, productive schizophrenia. Psychiatry Res 1999;90:169-179.

12. Wuebben $Y$, Winterer G. Hypofrontality: a risk marker related to schizophrenia ? Schizophrenia Res 2001;48:207-217.

13. Ingvar DH, Sjolund B, Ardo A. Correlation between dominant EEG frequency, cerebral oxygen uptake and blood flow. Electroenceph Clin Neurophysiol 1976;41:268-276.

14. Lemere F. Cortical energy production in the psychoses. Psychosom Med 1941;3:152-162.

15. Fenton GW, Fenwick PBC, Dollimore J, Dunn, TL, Hirsch SR. EEG spectral analysis in schizophrenia. Br J Psychiatry 1980;136:445-455.

16. Dierks T, Maurer K, Ihl R, Schmidtke A. Evaluation and interpretation of topographic EEG data in schizophrenic patients. In Maurer K (ed). Topographic brain mapping of EEG and evoked potentials Berlin: Springer 1989:507-517.

17. Gevins A, Smith ME, McEvoy LK, Leong H, Le Jian. Electroencephalographic imaging of higher brain function. Phil Trans R Soc Lond 1999;354:1125-1134.

18. Michel CM, Koukkou M, Lehmann D. EEG reactivity in high and low symptomatic schizophrenics, using source modeling in the frequency domain. Brain Topogr 1993;5:389-394.

19. Dierks T, Strik WK, Maurer K. Electrical brain activity in schizophrenia described by equivalent dipoles of FFT-data. Schizophrenia Res 1995;14:145-154.

20. Pascual-Marqui RD, Michel CM, Lehmann D. Low resolution electromagnetic tomography: a new method for localizing electrical activity in the brain. Int J Psychophysiol 1994;18:49-65.

21. Pascual-Marqui RD. Source localization: continuing discussion of the inverse problem. ISBET Newsletter 1995;6:9-30.

22. Talairach J, Tournoux P. Co-planar stereotaxic atlas of the human brain. Stuttgart: Thieme. 1988.

23. Friston KJ, Poline JB, Holmes AP, Price CJ, Frith, CD. Detecting activation in PET and fMRI: levels of inference and power. Neuroimage 1996;4:223-235.

24. Benes FM, Bird ED. An analysis of the arrangement of neurons in the cingulate cortex of schizophrenic patients. Arch Gen Psychiatry 1987;43:31-35.

25. Dolan RJ, Fletcher P, Frith CD, Friston KJ, Frackowiak RS, Grasby PM. Dopaminergic modulation of impaired cognitive activation in the anterior cingulate cortex in schizophrenia. Nature 1995;378:180-182.

26. Carter CS, Mintun M, Nichols T, Cohen JD. Anterior cingulate gyrus dysfunction and selective attention deficits in schizophrenia: $\mathrm{w} 15 \mathrm{OxH}$ O PET study during single trial stroop task performance. Am J Psychiatry 1997;154:1670-1675.

27. Mulert C, Gallinat J, Pascual-Marqui R, et al. Reduced event-related current density in the anterior cingulate cortex in schizophrenia. Neuroimage 2001;13:589-600.

28. Mientus S, Gallinat J, Wuebben Y, et al. Cortical hypoactivation during resting EEG in schizophrenics but not in depressives and schizotypal subjects as revealed by low resolution electromagnetic tomography (LORETA). Psychiatry Res 2002;116:95-111.

29. Smith M, McEvoy L, Gevins A. Neurophysiological indices of strategy development and skill acquisition. Cogn Brain Res 1998;7:389-404.

30. Koukkou M, Tremel E, Manske W. A psychobiological model of the pathogenesis of schizophrenic symptoms. Int J Psychophysiol 1991;10:203-212. 